\title{
Demonstration project of the solar hydrogen energy system located on
} Taleghan-Iran: Technical-economic assessments

\author{
Abolfazl Shiroudi ${ }^{1}$, Seyed Reza Hosseini Taklimi ${ }^{2, *}$ \\ ${ }^{1}$ Ministry of Energy-Renewable Energy organization of Iran (SUNA), Tehran, Iran \\ ${ }^{2}$ Linkoping University of Technology, Linkoping, Sweden \\ * Corresponding author. Tel: +46 760830785, E-mail: seyho130@student.liu.se
}

\begin{abstract}
One of the most attractive features of hydrogen as an energy carrier is that it can be produced from abundant material like water. The use of electrolysis to produce hydrogen from water is an efficient method from small to large scales. Energy for supplying water electrolysis systems can be provided by photovoltaic arrays. During the daylight hours, the sunlight on the photovoltaic arrays converts into electrical energy which can be used for electrolyzer. The hydrogen produced by the electrolyzer is compressed and stored in hydrogen vessel and provides energy for the fuel cell to meet the load when the solar energy is insufficient. This study investigates a stand-alone power system that consists of $10 \mathrm{~kW} \mathrm{PV}$ arrays as power supply and $5 \mathrm{~kW}$ electrolyzer. They have been integrated and worked at Taleghan site in Iran. Result was simulated and optimized by using HOMER simulation tools and techno-economic analysis of system presented in this paper.
\end{abstract}

Keywords: Hydrogen, PV array, Electrolyzer, Fuel cell, HOMER

\section{Introduction}

Renewable energy (RE) sources are attracting more attention as alternative energy sources nowadays. Depletion of energy sources and global warming play big role in this movement [1]. RE sources can open a new ways to solve these environmental issues. They usually free of pollution during development and operation for power generation [2]. Integration of RE with energy storage would provide a better system reliability making it suitable for remote stand-alone applications [3]. Among these sources, solar energy is an important kind of them. Solar photovoltaic (PV) energy has been widely utilized in small size application and is the most promising candidate for research and development for large-scale use, as the fabrication of less costly PV devices becomes a reality [1]. Seasonal solar energy which stores in the form of hydrogen can provide the basis for a completely renewable energy system. One of the most promising applications is stationary stand-alone power systems, particularly those located in remote areas where the cost of transporting fuel is high [4]. There is a growing awareness that hydrogen is the fuel of the future. Solar hydrogen is a leading candidate for a renewable and environmentally safe energy carrier [5]. Iran with more than $4.5 \mathrm{kWh} / \mathrm{m}^{2}$.day radiations has a great potential for attracting and converting it to electricity. One of the efforts done in the field of constructing and utilization solar hydrogen plant is constructing standalone power system PV- electrolyzer- fuel cell in Taleghan site. The current paper evaluates the techno-economic aspects of PV-Electrolyzer-Fuel cell system. Hybrid optimization model for electric renewable (HOMER) was used as the simulation and optimization tools. The schematic of the plant at Taleghan site is given in Fig. 1.

\section{Methodology}

Hybrid systems based on the synergy between RE sources and conventional energy systems can be a reliable solution for remote sites to provide their need of energy. In this study, first PV cells hourly data of Electricity production gathered. Specification of each units in system such as PV array, water electrolysis, hydrogen storage tank, a f uel cell and a Power Management Unit (PMU) collected and they used for design and calculating primary model of HOMER. Then model optimized by software and the results of techno-economic analysis of 
integration between PV panels, alkaline water electrolysis and hydrogen storage tank are presented.

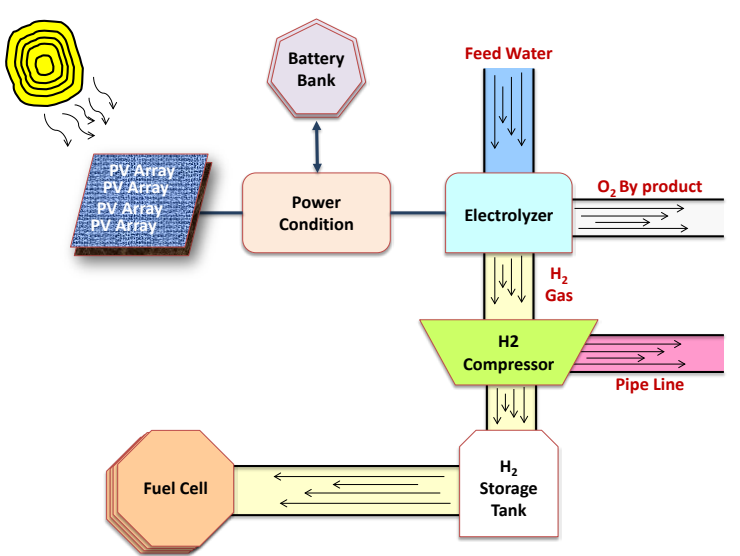

Fig. 1. Schematic of the PV-Electrolyzer-Fuel cell energy system at the Taleghan site

\section{Result}

\subsection{Description of the system}

This stand-alone energy system is located in altitude $1700 \mathrm{~m}$ and consists of a $10 \mathrm{~kW}$ pV array coupled to a $5 \mathrm{kWe}$ bipolar, alkaline electrolyzer, a gas hydrogen storage tank $\left(1 \mathrm{~m}^{3}\right)$, battery banks, converters DC/AC and a PMU. When the sun shines, PV power is available and it used directly to supply the load. Then electrolyzer turns on for producing hydrogen, which is delivered to the hydrogen storage tanks. In absent of solar the $1.2 \mathrm{~kW}$ Proton Exchange Membrane (PEM) fuel cell will begin to produce energy for the load using hydrogen from the hydrogen storage tank to produce the necessary electricity [6]. The PMU is in charge of the conversion and the dispatching of the energy between each component. It is composed of many converters and an inverter as well as a PLC, programmed to optimally switch on or off system components [7].

\subsubsection{PV array}

Solar energy is one type of the RE resources, which can be converted easily and directly to the electrical energy by PV converters. The PV array consists of 224 solar panels MA36/45 modules configured into 14 independent sub arrays. The array is broken into sub arrays that are each individually controlled. Each sub-array consists of 16 modules, which connected in parallel of seven modules in series. The nominal power rating for the array is $10 \mathrm{~kW}_{\mathrm{p}}$. The PV module is a polycrystalline silicon type with maximum output of $45 \mathrm{~W}$. Each module is 462 mm wide and $977 \mathrm{~mm}$ long for an area of $0.45 \mathrm{~m}^{2}$ per module and total surface of $101.1 \mathrm{~m}^{2}$ $\left(2 \times 7 \times 16 \times 0.45=101.1 \mathrm{~m}^{2}\right)$.

Table 1. Photovoltaic Module Electrical characteristics (MA 36/45)

$\begin{array}{lclc}\text { Nominal power } & 45 \mathrm{~W} & \text { Short circuit current } & 2.96 \mathrm{~A} \\ \text { Nominal load voltage } & 20.5 \mathrm{~V} & \text { Current at maximum power point } & 2.74 \mathrm{~A} \\ \text { Voltage in maximum power point } & 16.7 \mathrm{~V} & \text { Nominal efficiency } & 0.115\end{array}$

The tilt angle is fixed at 45 degree with horizontal in south direction [8]. The specifications of the modules in the standard condition $\left(1000 \mathrm{~W} / \mathrm{m}^{2}\right.$ radiation $\& 25^{\circ} \mathrm{C}$ temperature $)$, are listed in Table 1 [9]. 


\subsubsection{The Battery Bank}

Due to the stochastic nature of photovoltaic system, energy storage is needed to supply the load "on demand" by storing energy during periods of high bright sun. When the total output of the PV array is more than the energy demand, the battery bank is charged. The battery used in this system consists of $57.6 \mathrm{kWh}(12 \mathrm{~V} \times 100 \mathrm{Ah} \times 48 \mathrm{cell})$. The $48 \mathrm{~V}$ battery bank originally consisted of $57.6 \mathrm{kWh}$ of storage in $(12 \times 4)$ sealed, valve-regulated, deep-cycle batteries.

\subsubsection{The Inverter}

These units turn DC power into conventional AC power, as well as offer the ability to provide backup power during a power outage. When you need to use an electrical appliance, but only have access to DC power, an inverter is perfect. The inverter used in this project is a Sunny Boy model $2500 \mathrm{U}$. It is based on a power unit that operates with a very high efficiency and optimal reliability. It is designed for strings with 18 to $24 \mathrm{~s}$ tandard modules connected in series. For more detailed specifications, see Table 2 [10].

Table 2. Inverter technical characteristics (Sunny Boy model 2500)

$\begin{array}{lclc}\mathrm{P}_{\text {nominal }} & 2200 \mathrm{~W}_{p} & \text { Max. AC-power } & 2500 \mathrm{~W} \\ \text { Max input voltage } & 600 \mathrm{~V} & \text { Peak inverter efficiency }\left(\eta_{\max }\right) & 93-94.4 \% \\ \text { Max input current } & 11.2 \mathrm{~A} & \text { AC input frequency } & 49.8-50.2 \mathrm{~Hz} \\ \text { PV-voltage range MPPT } & 250-600 \mathrm{~V} & \mathrm{~V}_{\mathrm{AC}} & 198-251 \mathrm{~V}\end{array}$

\subsubsection{Electrolyzer}

Water electrolysis technology has the highest energy efficiency in non-fossil fuel based hydrogen production and is ideally suited for coupling with intermittent RE sources. In this method, electricity is used to split water into hydrogen and oxygen [11]. Water electrolysis is particularly suitable to be used in conjunction with PV array. The electrolyzer used in this project is a bipolar alkaline type. The electrolyzer module consists of 10 cells in series. The nominal operating point is rated load, 250 amperes and rated voltage, $25 \mathrm{~V}_{\max }$. The electrolyte $(\mathrm{KOH})$ concentration inside the cells is about $28 \mathrm{wt}$. \%. It had a maximum power of $5 \mathrm{~kW}$ and yielded about $1 \mathrm{Nm}^{3} / \mathrm{h}$ hydrogen at normal conditions and a purity of $99.9 \%$. Under nominal condition, the efficiency of system is $70 \%$.

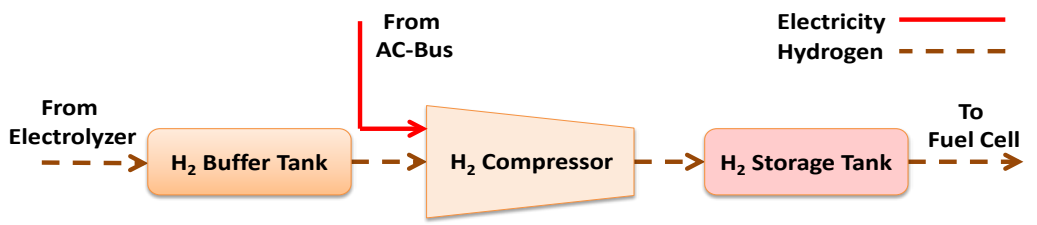

Fig. 2. Schematic of hydrogen storage system

The oxygen gas is far from pure as it leaves the electrolyzer's cells. The oxygen output of the electrolyzer still contains small amounts of hydrogen gas and vast amounts of water vapor [12-13]. The hydrogen from the electrolyzer is sent into a low-pressure tank (buffer tank) that is kept at a pressure lower than the hydrogen output pressure of the high-pressure tank as shown in Fig. 2. The intermediate reservoir system is used so that the compressor is only run when sufficient excess energy is available eliminates the use of energy from the fuel cell or enlargement of the battery bank to power the compressor. Compression occurs during compressor cycles in which the hydrogen is continuously removed from the low-pressure tanks beginning at the current pressure of the low-pressure tank and ending when the pressure 
drops to a specified minimum supply pressure. The hydrogen gas is then compressed by about 10 bars by the compressor and sent for storage to hydrogen vessel.

\subsubsection{Fuel cell}

A fuel cell is an energy conversion device, which converts the chemical energy of a fuel and oxidant, often hydrogen and oxygen, to electrical energy fuel cells are similar to batteries, however, unlike battery a fuel cell must be continuously provided with fuel, rather than deriving energy from materials contained within the cell, and the products of the electrochemical reaction must be removed the cell. They can achieve operating efficiencies approaching $60 \%$ nearly twice the efficiency of conventional internal combustion engines [14]. The outputs of the fuel cell are DC electricity and water. Fuel cells are a very attractive option to be used with intermittent sources of generation like the PV. Their feasibility in coordination with PV systems has been successfully demonstrated for both grid-connected and stand-alone applications [15]. A PEM fuel cell was chosen because of its passive operation, high efficiency, silent and its ability to provide power quickly from a standby configuration. In this project, The Nexa ${ }^{\mathrm{TM}}$ system has 30 cells and provides up to $1.2 \mathrm{~kW}$ of unregulated DC power at a nominal output voltage of $26 \mathrm{~V}_{\mathrm{DC}}$. The output voltage varies with power, ranging from about $43 \mathrm{~V}$ at system idle to about $26 \mathrm{~V}$ at full load [16].

\subsubsection{Hydrogen Storage}

Hydrogen as an energy carrier must be stored to overcome daily and seasonal discrepancies between energy source availability and demand. Hydrogen storage has an economic advantage over lead acid batteries for long-term storage. Currently, pressurized tanks are still the most cost-effective means of hydrogen storage for most applications [17]. It is known that a stand-alone energy system needs a storage system to provide energy for the cases of inappropriate weather conditions, instantaneous overload conditions, or demand for energy after sunset [18]. In this project, hydrogen gas produced in the electrolyzer at 10 bars. This gas is stored in one hydrogen storage tank $\left(1 \mathrm{~m}^{3}\right)$ with a rated working pressure of 10 bars.

\subsection{Advantages of the PV-Electrolysis system}

There are three main reasons why the PV efficiency is lower than we had hoped. First, the MA36/45 modules are rated at $45 \mathrm{~W}$ but when we tested them, the average output was lower than the manufacturer claimed. Second, the various wiring connections required by code add up to an appreciable voltage drop. And finally, the electrolyzer operating voltage usually doesn't exactly match the maximum power voltage of the array. The match between the electrolyzer and PV array is an important aspect of solar hydrogen system design [19]. Advantages of the PV-Electrolysis system:

- PV modules are sold with a warranty that guarantees the power generation for typically 25 years [10].

- PV modules are an ideal power supply for an electrolyzer. The output voltage of a PV array is DC and is roughly constant with illumination level. This is a good match to the electrolyzer, which requires a c onstant voltage of at least $1.9 \mathrm{~V}_{\mathrm{DC}}$ (for the generic considered). Increasing PV current would increase the overall volume of hydrogen produced, although it would also slightly lower the production efficiency [20].

- The water electrolysis and PV array can be sized independently and located separately. In this system, consumption power consists of $5 \mathrm{~kW}$ water electrolysis and $1.5 \mathrm{~kW}$ hydrogen compressors. In eight hours continuous working of electrolyzer, hydrogen compressor work just three hours; therefore total of demand energy in one-work days equal to: 


$$
E_{\text {total }}=\left(P_{\text {elec }} \times h_{1}\right)+\left(P_{\text {pump }} \times h_{2}\right)=[(5 \mathrm{~kW}) \times(8 \text { hours })]+\left[(1.5 \mathrm{~kW}) \times\left(6 \times \frac{1}{2} \text { hours }\right)\right]=44500 \mathrm{Wh} / \text { days }
$$

The average annual global radiation for Taleghan region is $4.5 \mathrm{kWh} / \mathrm{m}^{2}$; Therefore power of PV system in this pilot equal to:

$$
P_{P V}=\frac{44500 \mathrm{Wh} / \text { days }}{4500 \mathrm{Wh} / \mathrm{m}^{2}}=9.88 \mathrm{~kW} \approx 10 \mathrm{~kW}
$$

The Depth of discharge (DOD) is defined as the amount of energy that has been removed from a battery or battery pack and usually expressed as a percentage of the total capacity of the battery. In this case, $30 \%$ DOD means that $30 \%$ of the energy has been discharged, so the battery now holds only $70 \%$ of its full charge [21]. In this pilot, we used type of sealed lead acid with technical properties, $12 \mathrm{~V}$ and $100 \mathrm{Ah}$.

$$
\begin{aligned}
& \text { Bank capacity }=44500(\text { Wh } / \text { days }) \times \% 130(D O D)=57850 \mathrm{Wh} \\
& \text { Bank capacity }=\frac{57850 \mathrm{Wh}}{12 \mathrm{~V}}=4820 \mathrm{Ah} \\
& \text { No.Battery }=\frac{4820 \mathrm{Ah}}{100 \mathrm{~A}}=48.2 \approx 48
\end{aligned}
$$

\subsection{Simulation solar hydrogen system with HOMER tools}

National Renewable Energy Laboratory's software HOMER is used to select an optimum energy system. It also performs sensitivity analysis to evaluate the impact of a change in one or more of input parameters. Some required input information for HOMER are electrical loads, renewable resources, component technical/costs, constraints, controls, type of dispatch strategy, etc. [22]. The schematic of this system is shown in Fig. 3. Several simulation have been made by considering different capacities of PV panels, hydrogen tank, electrolyzer, battery bank, converter, fuel cell and primary load that the results of simulation, optimization and analysis for this system are described in the following sections:

- A cost of $342 \$ / 45 \mathrm{~W}$ was used, resulting in a total capital cost of $76000 \$$ for a $10 \mathrm{~kW} \mathrm{PV}$ array. PV array operation and maintenance (O\&M) cost is considered practically zero and their lifetime is 20 years. After some preliminary runs with HOMER, it was decided that the most suitable PV size to be considered was $10 \mathrm{~kW}$.

- A battery bank with a capacity of $1200 \mathrm{Ah}(12 \mathrm{~V}, 100 \mathrm{~A})$ per unit was installed. The total capacity of batteries installed was $57.6 \mathrm{kWh}$ and the estimated lifetime was 5 years. The total capital cost of the battery bank was 4896 \$. S izes of batteries considered in the optimization were: 48 and $0 \mathrm{kWh}$ (no batteries).

- An AC-DC power converter unit has been installed in PV-Hydrogen system of Taleghan site. Power conditioning capital cost is around $600-800 € / \mathrm{kW}$ [23]. A cost of $1350 \$ / \mathrm{kW}$ was chosen for Taleghan site. A lifetime of 20 years was assumed and a converter efficiency of $>94 \%$.

- The cost of hydrogen production unit integrated to the proposed PV-hydrogen cost was $2700 \$$ per $\mathrm{Nm}^{3} / \mathrm{h} \mathrm{H}_{2}$. The introduction of this unit sizes $(0-6.5 \mathrm{~kW})$ was investigated with HOMER. The lifetime of this unit was considered as equal to 10 years.

- The capital cost of Nexa system $(1.2 \mathrm{~kW})$ is $5000 \$ / \mathrm{kW}$ for the stand-alone energy system in Taleghan site (because of its very small-scale). Fuel cell lifetime was 1500 operating 
hours. Three different PEM fuel cell size (1-1.2 kW) were considered in the calculations performed with HOMER and electrical efficiency assumed constant at $38 \%$.

- Compressed gas storage is used for this study. Small-quantity prices are around $1500 \$ / \mathrm{kg}$. A hydrogen storage tank options was investigated in the optimization process, namely $1 \mathrm{Nm}^{3}(\approx 1 \mathrm{~kg})$ and the lifetime were also considered 20 years [23].

- This system has an average AC load of $31 \mathrm{kWh} /$ days, with the peak load of $2.9 \mathrm{kWh} /$ days. HOMER allows input of the operating reserve for the system. Result of here required the operating reserve to be $10 \%$ of the hourly load, plus $25 \%$ of PV power output.

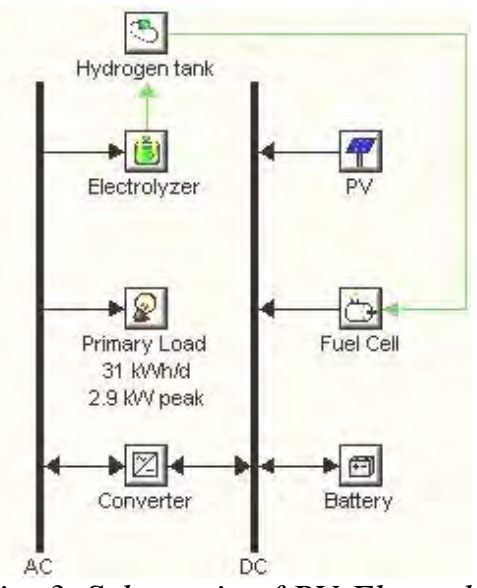

Fig. 3. Schematic of PV-Electrolyzer-Fuel cell power system

\section{4. $\quad P V$-hydrogen system optimization results}

Actual load profile and meteorological data from the operation of the PV-fuel cell system in Taleghan site were used in this study. Hourly solar radiation measurements for a period of one year were imported into HOMER tools in order to calculate monthly average values of clearness index and daily radiation [24]. According to data from Taleghan area, the solar radiation is high, especially between June and August. The annual average global radiation is $4.5 \mathrm{kWh} / \mathrm{m}^{2}$.day with an annual average clearness index of 0.62 a nd the average daily radiation is $5.095 \mathrm{~kW} \mathrm{~h} / \mathrm{m}^{2}$. The existing system was simulated in order to evaluate its operational characteristics, namely annual electrical energy production; annual electrical loads served, excess electricity, RE fraction, capacity shortage, unmet load etc. some environmental impact parameters of the system. A load-following control strategy was followed in the simulation. Under this strategy, whenever a power generator in needed it produces only enough power to meet the demand. Load following strategy tends to be optimal in systems with a surplus of renewable energy. An annual interest rate of $10 \%$ and a project of 20 years were used in the economic calculations [24].

Table 3. Electrical production and demand for the stand-alone system

\begin{tabular}{|c|c|c|c|c|c|}
\hline \multicolumn{2}{|c|}{$\begin{array}{l}\text { Annual Electric Energy } \\
\text { Production }\end{array}$} & \multicolumn{2}{|c|}{$\begin{array}{l}\text { Annual Electric Energy } \\
\text { Consumption }\end{array}$} & \multicolumn{2}{|l|}{ Other } \\
\hline PV Array & $\begin{array}{l}18025 \mathrm{kWh} \\
(99 \%)\end{array}$ & AC Primary Load & $\begin{array}{l}11116 k W h \\
(98 \%)\end{array}$ & Excess Power & $4109 \mathrm{kWh} /$ years \\
\hline Fuel Cell & $\begin{array}{l}101 \mathrm{kWh} \\
(1 \%)\end{array}$ & Electrolyzer Load & $\begin{array}{l}392 \mathrm{kWh} \\
(2 \%)\end{array}$ & $\begin{array}{l}\text { Capacity } \\
\text { Shortage }\end{array}$ & $157 \mathrm{kWh} /$ years \\
\hline $\begin{array}{l}\text { Renewable } \\
\text { Fraction }\end{array}$ & $100 \%$ & Total & $11508 \mathrm{kWh}$ & $\begin{array}{l}\mathrm{CO}_{2} \\
\text { Emissions }\end{array}$ & $0.0619 \mathrm{~kg} /$ year \\
\hline
\end{tabular}

The results of the simulation showed that this system had a total annual electrical energy production of $18126 \mathrm{kWh}$, the RE fraction of which was $\approx 1$ (i.e. $18025 \mathrm{kWh}$ were produced 
by the PV array). All results related to the electric energy production and electric energy consumption is summarized in Table 3. Latter is attributed to high nighttime load, which enable the operation of fuel cell because PV energy stored in batteries is not adequate to serve the load overnight. To increase renewable energy penetration excess energy can be stored in the form of compressed hydrogen and drive a PEM fuel cell.

Table 4. Distribution of annualized costs for the main components of the stand-alone energy system

\begin{tabular}{lcccccc}
\hline Component & $\begin{array}{c}\text { Initial } \\
\text { Capital } \\
(\$)\end{array}$ & $\begin{array}{c}\text { Annualized } \\
\text { Capital } \\
(\$ / \text { year })\end{array}$ & $\begin{array}{c}\text { Annualized } \\
\text { Replacement } \\
(\$ / \text { year })\end{array}$ & $\begin{array}{c}\text { Annual } \\
\text { O\&M } \\
(\$ / \text { year })\end{array}$ & $\begin{array}{c}\text { Annual } \\
\text { Fuel } \\
(\$ / \text { year })\end{array}$ & $\begin{array}{c}\text { Total } \\
\text { Annualized } \\
(\$ / y e a r)\end{array}$ \\
\hline PV Array & 76000 & 8927 & 0 & 0 & 0 & 8927 \\
Fuel Cell & 5000 & 587 & 88 & 12.1 & 0 & 687 \\
Battery & 4896 & 575 & 320 & 0 & 0 & 895 \\
Converter & 13650 & 1603 & 0 & 0 & 0 & 1603 \\
Electrolyzer & 8100 & 951 & 272 & 0 & 0 & 1223 \\
Hydrogen Tank & 1500 & 176 & 0 & 0 & 0 & 176 \\
Other & 0 & 0 & 0 & 0.2 & 0 & 0 \\
\hline
\end{tabular}

The Electrical production and demand of this system are listed in Table 3. When excess PV energy is available, power is supplied first to the batteries, and then to an electrolyzer, which generate hydrogen for storage. By using HOMER it can be decided whether to use energy from the battery, fuel cell, or both based on the replacement cost and O\&M of the devices. PV-Hydrogen system components are described in more detail in the following sections. Total annualized costs for each component of the stand-alone energy system are shown in Table 4. This is attributed to the fact that the lifetime of batteries is only 5 years, and the system lifetime is 20 years. Therefore the battery bank needs to be replaced several times during the project. The total net present cost (NPC) of this system at Taleghan site is around $115034 \$$ and cost of energy (COE) of the proposed hydrogen system is $1.216 \$ / \mathrm{kWh}$.

\section{Conclusions}

The replacement of conventional technologies, namely batteries by hydrogen technologies including fuel cells in RE resources based stand-alone power systems is technologically feasible. It reduces emissions, noise and fossil fuel dependence and increases RE penetration. The coupling of PV field and electrolyzer allows converting at high efficiency renewable electricity. There is no loss whatever the storage time and no need of consumption to avoid storage destruction. Using a fuel cell to get back to electricity induces a low efficiency but allows building a silent energy generator consuming no materials. New energy generators for stand-alone applications are expected to increase the comfort of people. The actual solutions are either limited by a low autonomy inducing reduction of the electricity consumption during worst seasons or noisy and using fossil energy. The coupling of a PV field and an electrolyzer allows converting at high efficiency renewable electricity into time-stable storage from pure water. Using a fuel cell to get back to electricity allows building a noiseless energy generator consuming no materials. The gas storage induces a complete autonomy during all the years and should increase the use of the renewable production. Iran country located on solar belt, so it has great potentional in direct natural insolation for consuming and converting it to other types of energy. Using solar energy required high initial investment, so converting solar 
energy to other types of energy with high efficiency systems is vital. Photovoltaic technology provides a reliable energy for producing hydrogen by electrolysis. Constructing this project illustrates photovoltaic system reliability, availability and being disputable in rural areas and end point of electricity yield. (Conclusion extract from) system operation conclusions shows equal real outputs, which calculated data and this, will be a start for gathering and processing information from operational parameters, in software.

\section{References}

[1] K. Ro, S. Rahman, IEEE Transactions on Energy Conversion 13 (3), 1998, pp. 276-281.

[2] A.M. Ramirez, P.J. Sebastian, S.A. Gamboa, M.A. Rivera, O. Cuevas, J. Campos, Int J Hydrogen Energy 25, 2000, pp. 267-271.

[3] W. Isherwood, J.R. Smith, S.M. Aceves, G. Berry, W. Clark, R. Johnson, D. das, D. Goering, R. Seifert, Solar Energy 25, 2000, pp. 1005-1020.

[4] Ø. Ulleberg, Solar Energy 76, 2004, pp. 323-329.

[5] S.A. Sherif, F. Barbir, T.N. Vezirouglu, Solar Energy 78, 2005, pp. 647-660.

[6] D.B. Nelson, M.H. Nehrir, C. Wang, Renewable Energy 31, 2006, pp. 1641-1656.

[7] S. Busquet, F. Domain, R. Metkemeijer, D. Mayer, Ecole des Mines de Paris-Centre d'Energétique, Rue Claude Daunesse, Les Lucioles-BP 207, F-06904 Sophia Antipolis.

[8] Technical Catalogue of Solar Module MA36/45,Optical Fiber Fabrication Company, Iran

[9] H. Moghbelli, R. Vartanian, International Conference on Renewable Energy for Developing Countries, 2006.

[10]www.SMA.de

[11]K.E. Cox, K.D. Williamson, Hydrogen: its technology and implications, Ohio: CRC Press Inc., 1977.

[12]P. Hollmuller, J. Joubert, B. Lachal, K. Yvon, Int. J. Hydrogen Energy 25, 2000.

[13]R. Perez, Home Power 22, 1991, pp. 26-30.

[14]Fuel Cell Handbook, 6th ed., National Energy Technology Lab, U.S. DOE, Pittsburgh, PA, 2002.

[15] S. Rahman and K. Tam, IEEE Transactions on Energy Conversion 3 (1), 1988, pp. 50-55.

[16] Nexa'TM (310-0027) Power Module User's Manual, MAN5100078, 2003.

[17]J. Cotrell, W. Pratt, NREL/TP-500-34648, 2003.

[18]E. Koutroulis, K. Kalaitzakis, Renewable Energy 28 (1), 2003, pp. 139-152.

[19]P. Lehman, C. Parra, Solar Today, the American solar energy society, 1994, pp: 20-22

[20]N. Nagai, M. Takeuchi, T. Kimura, T. Oka, Int. J Hydrogen Energy 28, 2003, pp. 35-41.

[21] Solar Electric Products Catalog, August 2005.

[22] NERL. Hybrid Optimization Model for Electric Renewable (HOMER) Available freely at (http://www.nrel.gov/international/tools/HOMER/homer.html).

[23]E.I. Zoulias, N. Lymberopoulos, Renewable Energy 32, 2007, pp. 680-696.

[24]RETScreen ${ }^{\mathrm{TM}}$ database, URL: www.retscreen.net. 